๑) Open Access Full Text Article

CORRIGENDUM

\title{
A Smart Multifunctional Nanoparticle for Enhanced Near-Infrared Image-Guided Photothermal Therapy Against Gastric Cancer [Corrigendum]
}

\author{
Shao J, Liang R, Ding $\mathrm{D}$, Zheng $\mathrm{X}$, et al. The authors apologize for this error and advise it does not \\ Int J Nanomedicine. 2021;16:2897-2915. \\ affect the results of the paper.
}

\begin{abstract}
The authors have advised due to an error at the time of figure assembly, Figure $8 \mathrm{~F}$ on page 2911 is incorrect. The correct Figure 8 is shown below.
\end{abstract}


A

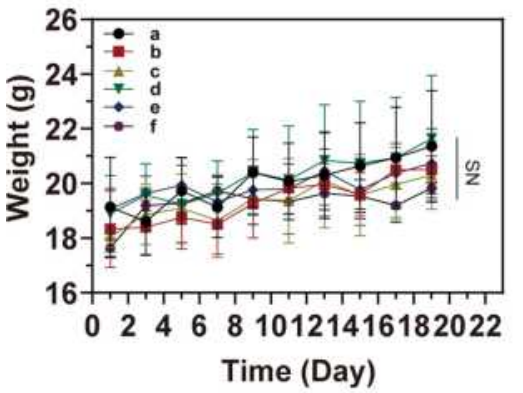

B

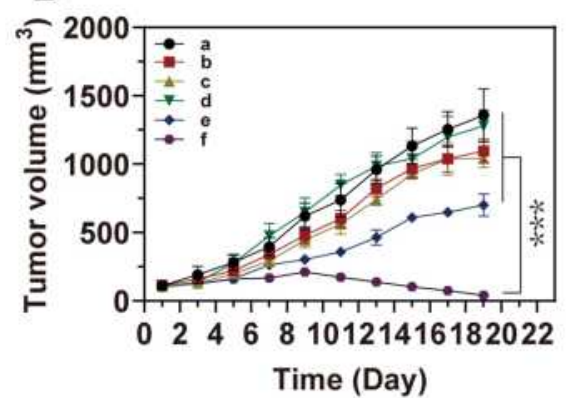

C

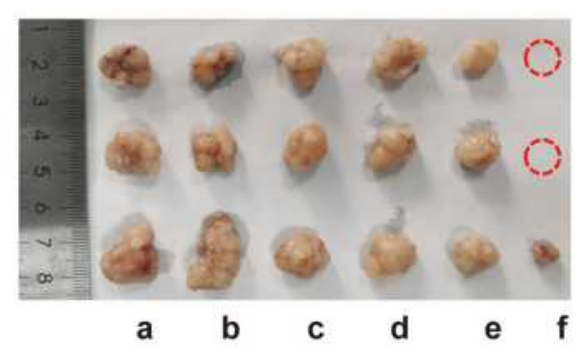

D

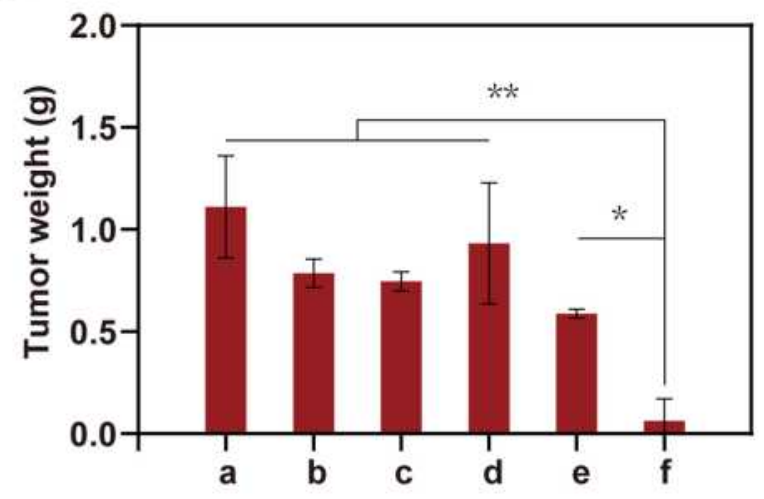

E

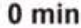

๓̊口
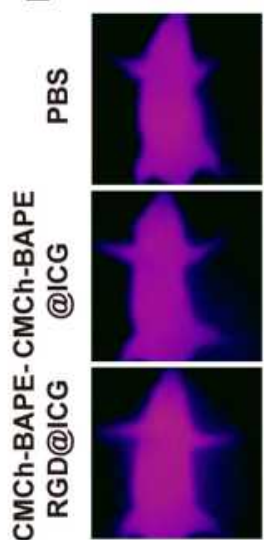

d
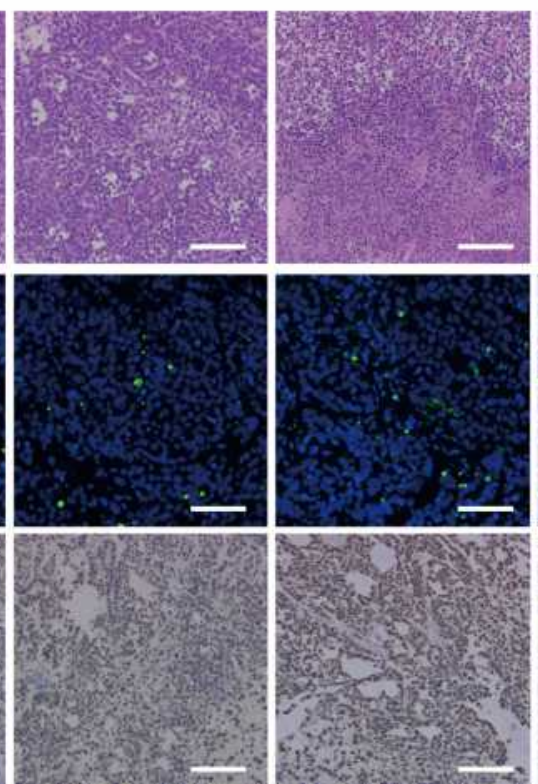

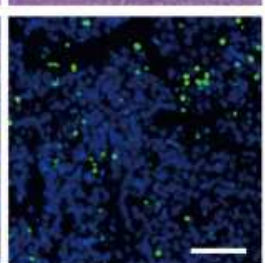

$1 \mathrm{~min}$

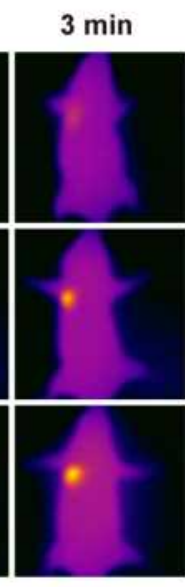

e
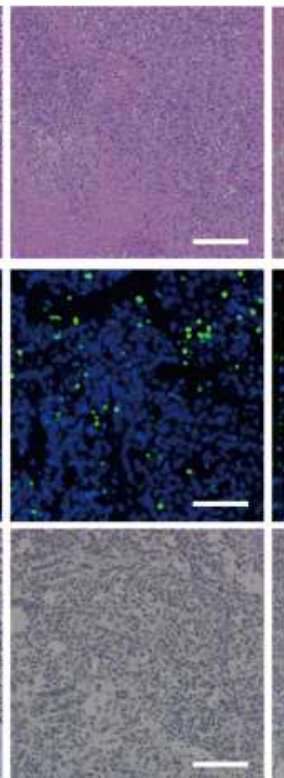
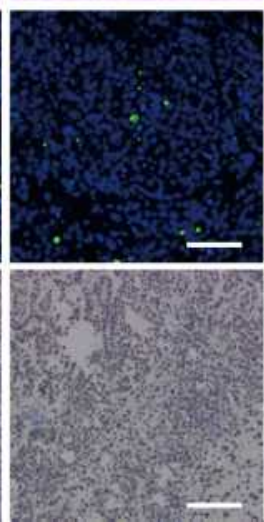

$5 \mathrm{~min}$

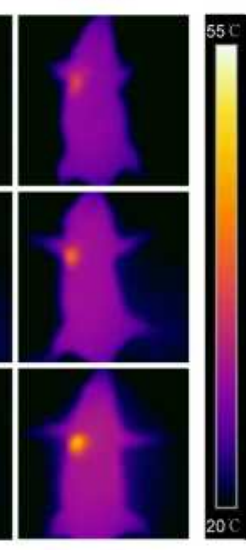

f
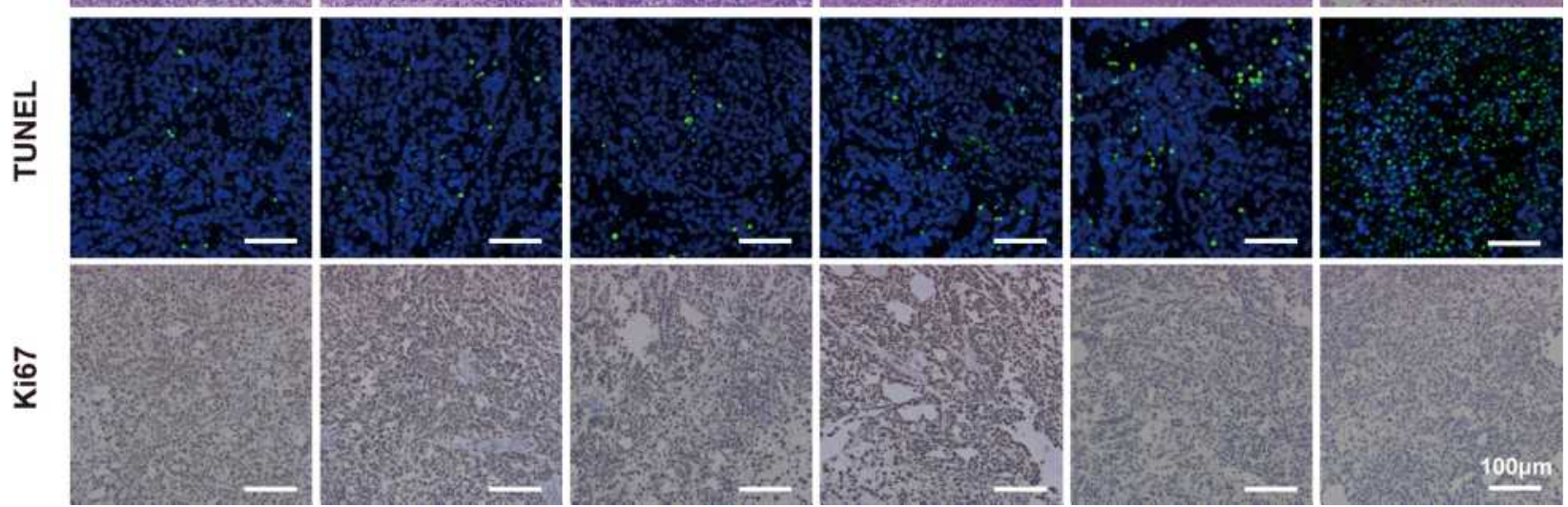

Figure 8 (A) Weight changes curve within 2I-day treatments of each group. (B) Tumor growth curve within 2I-day treatments of each group. (C) Images of tumor in each group collected on day 2I. (D) Average tumor weight in each group after 2 I-day treatment. (E) Infrared thermographic images of mice received different treatments. (F) H\&E, TUNEL and Ki67 staining of tumor sections in each group. Severely damaged tumor tissue are indicated by a black circle. Note that a-f represent different treatments: a. PBS, b. CMCh-BAPE@ICG, c. CMCh-BAPE-RGD@ICG, d. PBS+laser, e. CMCh-BAPE@ICG+laser, f. CMCh-BAPE-RGD@ICG +laser. (NS) P $\geq 0.05$. (*) P< 0.05, (**) P< 0.01 and $(* * *) P<0.001$ 


\section{Publish your work in this journal}

The International Journal of Nanomedicine is an international, peerreviewed journal focusing on the application of nanotechnology in diagnostics, therapeutics, and drug delivery systems throughout the biomedical field. This journal is indexed on PubMed Central, MedLine, CAS, SciSearch ${ }^{\mathbb{B}}$, Current Contents ${ }^{\mathbb{B}} /$ Clinical Medicine,
Journal Citation Reports/Science Edition, EMBase, Scopus and the Elsevier Bibliographic databases. The manuscript management system is completely online and includes a very quick and fair peer-review system, which is all easy to use. Visit http://www.dovepress.com/ testimonials.php to read real quotes from published authors.

Submit your manuscript here: https://www.dovepress.com/international-journal-of-nanomedicine-journal 